\title{
Effect of Soft-Fine Particle Peening on Rotating Bending Fatigue Properties of Gas Carburized SCM420H Steel
}

\author{
Shoichi KIKuchi ${ }^{1)^{*}}$, Koichiro Nambu ${ }^{2)}$, Yuki NaKamura ${ }^{3)}$ and Hiroyuki Akebono ${ }^{4)}$ \\ 1) Department of Mechanical Engineering, Faculty of Engineering, Shizuoka University \\ 2) Toyota Technological Institute \\ 3) Department of Mechanical Engineering, National Institute of Technology, Toyota College \\ 4) Department of Mechanical Science and Engineering, Hiroshima University
}

Abstract: In order to examine the effects of soft-fine particle peening (Soft-FPP) on the fatigue properties of gas carburized SCM420H steel, rotating bending fatigue tests were conducted for carburized SCM420H steels treated with FPP using shot particles having different hardness. The Soft-FPP treated steels pre-treated with carburizing showed higher fatigue life and fatigue strength at $10^{7}$ cycles compared with the only-carburized steels. This is attributed to the increase of surface hardness and the generation of compressive residual stress induced by FPP. The carburized steels treated with FPP failed in the subsurface fracture mode from the singular microstructure beneath the carburized layer in the long life region. The transition stress for the carburized steels treated with FPP, at which the surface fracture mode changed to the subsurface one, tended to increase with the hardness of shot particles used in FPP. Furthermore, the release behavior of residual stress induced by FPP during fatigue tests was also examined. There were no noticeable differences in compressive residual stress after the fatigue tests between the two types of carburized specimens treated with FPP; therefore, the Soft-FPP treated steels exhibited same fatigue strength as the steels treated with FPP using hard shot particles. These results suggest that the effect of hardness of shot particles used in FPP on the fatigue properties of carburized steels is not observed.

Keywords: fatigue; fine particle peening; residual stress; hardness; carburizing.

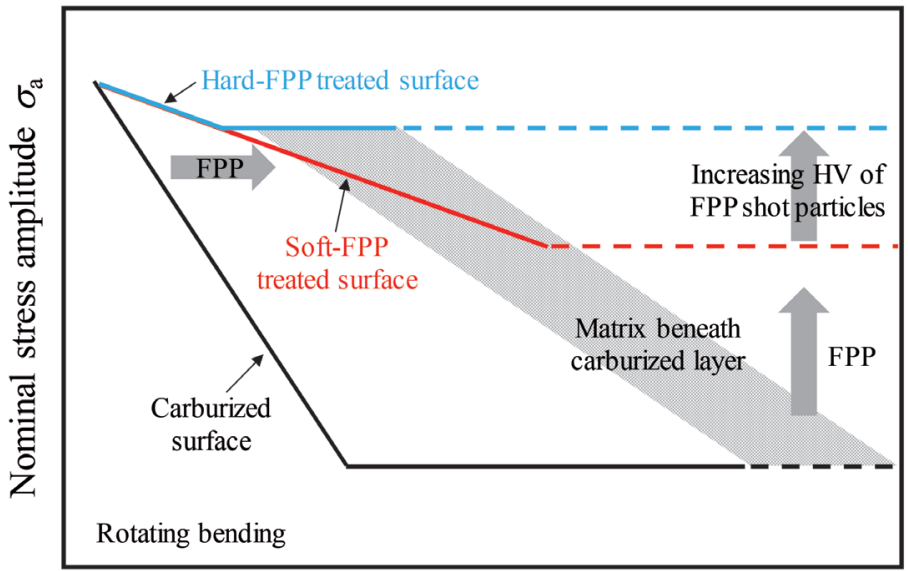

Log (Number of cycles to failure $\left.N_{\mathrm{f}}\right)$ 


\title{
ガス浸炭焼入れを施したSCM420H 鋼の回転曲げ疲労特性 に及ぼす軟質微粒子ピーニングの影響
}

\author{
菊池 将一 ${ }^{1) *} \cdot$ 南部 紘一郎 ${ }^{2)} \cdot$ 中村 裕紀 $^{3)} \cdot$ 曙 紘之 ${ }^{4)}$ \\ Effect of Soft-Fine Particle Peening on Rotating Bending Fatigue Properties of Gas Carburized SCM420H Steel \\ Shoichi Kikuchi, Koichiro Nambu, Yuki NaKamura and Hiroyuki AKeBono
}

\section{1. 緒言}

近年, 地球環境保護の観点から, 二輪車に搭載する変速 機の軽量化打よび小型化の需要が高まっている。二輪車の 変速機の場合, 自動車と比較して冷却が難しいことから, 小型化の実現には変速機を構成する各部品の高強度化が不 可欠である。なかでも内燃機関の駆動力伝達部品である茵 車には, 複数回の曲げ応力や摺動に耐える機能が要求され るため, 浸炭焼入れを施すことが多い ${ }^{1-4)}$ 。

浸炭焼入鋼のさらなる疲労特性改善には, ショットピー ニングによって鋼の表面組織を改質することが有効であ る ${ }^{3-8)}$ 。なかでも, 微細な投射粒子を用いる微粒子ピーニン グ (Fine particle peening: FPP) は, 従来のショットピーニン グと比較して高い圧縮残留応力を生起させることに加えて 微細な結晶粒を創製可能であるため ${ }^{9-13)}$, 材料の疲労特性 改善に有効である。Sawada ${ }^{7,8)}$ は, 高硬さの投射粒子 (ビッ カース硬さ $1550 \mathrm{HV)}$ を開発し，FPPを施した浸炭鋼の表 面に $1800 \mathrm{MPa}$ という極めて高い圧縮残留応力を生起させ ている。著者ら ${ }^{14,15)}$ は, 被処理材と投射粒子の硬さを系統 的に変化させ, 両者の硬さの比 (投射粒子硬さを被処理材 硬さで除した值）が 1.3 以上となる条件において，FPPに よって生起する圧縮残留応力值が増加することを明らかに している。これらの先行研究から, 材料表面に高い圧縮残 留応力を生起させるには, 硬い投射粒子を用いることが有 効であるとされている。

しかし実用的観点からは, 被処理材に対して投射粒子が 硬すぎると被処理面が摩耗したり, 粒子衝突痕が疲労破壞 の起点となる場合がある ${ }^{16)}$ 。したがって, 表面粗さの増加 や寸法精度も考慮すると，必ずしも硬い投射粒子を用いる ことは適切ではない。実際にMorikawa ${ }^{3)}$ は, FPPを施し
たガス浸炭歯車に対してナイロン歯車工具を用いたラッピ ングを施し, 歯面粗さの低減によって負荷能力が向上する ことを明らかにしている。また著者ら ${ }^{14,15}$ は, 前述の硬さ の比 (投射粒子硬さを被処理材硬さで除した值) が 1.3 未満 の条件でFPPを施すことにより, 表面粗さ值を増加させる ことなく压縮残留応力を生起させることに成功している。

そこで本研究では，あえて軟質の投射粒子を用いた ピーニング (軟質 FPP) を導入し，ガス浸炭焼入れを施し た SCM420H鋼の表面改質層の変化について検討を加え ることとした。また, 疲労過程において圧縮残留応力は変 化 ${ }^{14,17-21)}$ するため, 疲労試験前の初期残留応力值を評価す るのみならず度労試験後にいかに高い圧縮残留応力が残存 しているか，という点が材料の疲労特性改善には重要であ る。そのため, 回転曲げ疲労試験を行い, 浸炭焼入鋼の回 転曲げ疲労特性に及ぼすFPPの効果が投射粒子硬さによっ てどのように変化するかという点について, 疲労過程にお ける圧縮残留応力の解放挙動と関連づけて検討を加えた。

\section{2. 実験方法}

\section{$2 \cdot 1$ 供試材および試験片}

供試材には, Table 1 に示す化学成分を有するクロムモリ ブデン鋼 $(\mathrm{SCM} 420 \mathrm{H})$ の丸棒（直径 $35 \mathrm{~mm}$ ) を用いた。丸棒 は, 製鋼 (ビレット) 後に熱間圧延を施したままの状態で あり，その旧オーステナイト結晶粒度は8である。圧延ま

Table 1. Chemical composition of SCM420H (mass\%).

\begin{tabular}{cccccccccc}
\hline $\mathrm{C}$ & $\mathrm{Si}$ & $\mathrm{Mn}$ & $\mathrm{P}$ & $\mathrm{S}$ & $\mathrm{Cu}$ & $\mathrm{Ni}$ & $\mathrm{Cr}$ & $\mathrm{Mo}$ & $\mathrm{O}$ \\
\hline 0.21 & 0.25 & 0.85 & 0.019 & 0.016 & 0.01 & 0.02 & 1.1 & 0.16 & 0.0005
\end{tabular}

2020年2月28日受付２020年5月12日受理（Received on Feb. 28, 2020 ; Accepted on May 12, 2020)

1）静岡大学工学部機械工学科 (Department of Mechanical Engineering, Faculty of Engineering, Shizuoka University)

2) 豊田工業大学 (Toyota Technological Institute)

3）豊田工業高等専門学校機械工学科 (Department of Mechanical Engineering, National Institute of Technology, Toyota College)

4）広島大学大学院工学研究科（Department of Mechanical Science and Engineering, Hiroshima University)

* Corresponding author. E-mail : kikuchi.shoichi@shizuoka.ac.jp, Address : Shizuoka University, 3-5-1 Johoku Naka-ku Hamamatsu Shizuoka $432-8561$ 
まの受入れ材の平均硬さは $228 \pm 4 \mathrm{HV}$ (試験力 $0.98 \mathrm{~N}, n=$ 30)，機械的性質は Table 2 に示す通りである。Fig.1に，ナ イタールエッチングにより現出させた受入れ材の横断面組 織を, デジタルマイクロスコープにより観察した結果を示 す。同図から，受入れ材はフェライト・パーライト組織を 有していることがわかる。同材を, Fig.2に示す砂時計型の 疲労試験片 (応力集中係数 1.03) に機械加工した。なお, 浸 炭焼入れによる試験片の変形を抑制するために, 試験片の 掴み部には吊るしワイヤーを通す穴(直径 $4 \mathrm{~mm}$ ) を設けた。 このように機械加工した試験片 (As-received材) に対し て, カーボンポテンシャル $1.0 \%$ の条件でガス浸炭 $\left(900^{\circ} \mathrm{C}\right.$, $120 \mathrm{~min}$ ) を施した後, 油冷 (油温 $150^{\circ} \mathrm{C}, 10 \mathrm{~min}$ ) および焼

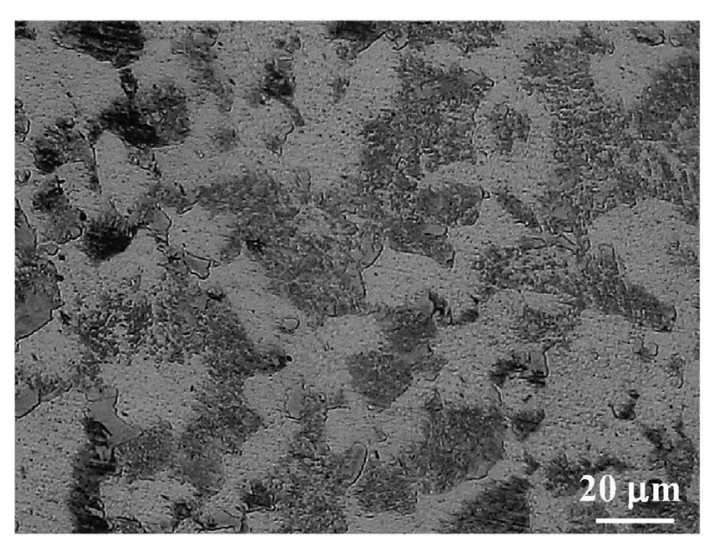

Fig. 1. Cross-sectional optical micrograph of as-received series etched with Nital.
戻し $\left(190^{\circ} \mathrm{C}, 80 \mathrm{~min}\right.$ 保持後に空冷) を実施した。以後, 浸 炭 (Carburizing) 処理材を C 材と呼称する。Fig.3に, ピクリ ン酸エッチングにより現出させた $\mathrm{C}$ 材の旧オーステナイト 粒界を，デジタルマイクロスコープにより観察した結果を 示す。同図には，(a) 浸炭層表層，（b）深さ $800 \mu \mathrm{m}, \quad(\mathrm{c})$ 深 さ2500 $\mu \mathrm{m}$ (試験片中心部) 近傍における観察結果を示し

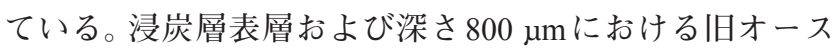
テナイト粒径は $17 \mu \mathrm{m}$, 深さ $2500 \mu \mathrm{m}$ (試験片中心部) 近傍 の旧オーステナイト粒径は2 $0 \mu \mathrm{m}$ であった。なお浸炭処理 後には, 旋盤を用いて疲労試験片の掴み部を直径 $15 \mathrm{~mm}$ に 機械加工し, 浸炭試験片両端の掴み部が平行となるよう工 夫した。

\section{$2 \cdot 2$ 微粒子ピーニング (FPP)}

浸炭処理後,一部のC材に対してFPPを施した。FPPは, 直圧式のエアノズル式ショットピーニング装置 (新東工業

Table 2. Mechanical properties of as-received material.

\begin{tabular}{ccc}
\hline Yield stress & Tensile strength & Elongation \\
\hline $344 \mathrm{MPa}$ & $688 \mathrm{MPa}$ & $19 \%$ \\
\hline
\end{tabular}

Fig. 2. Specimen configuration.
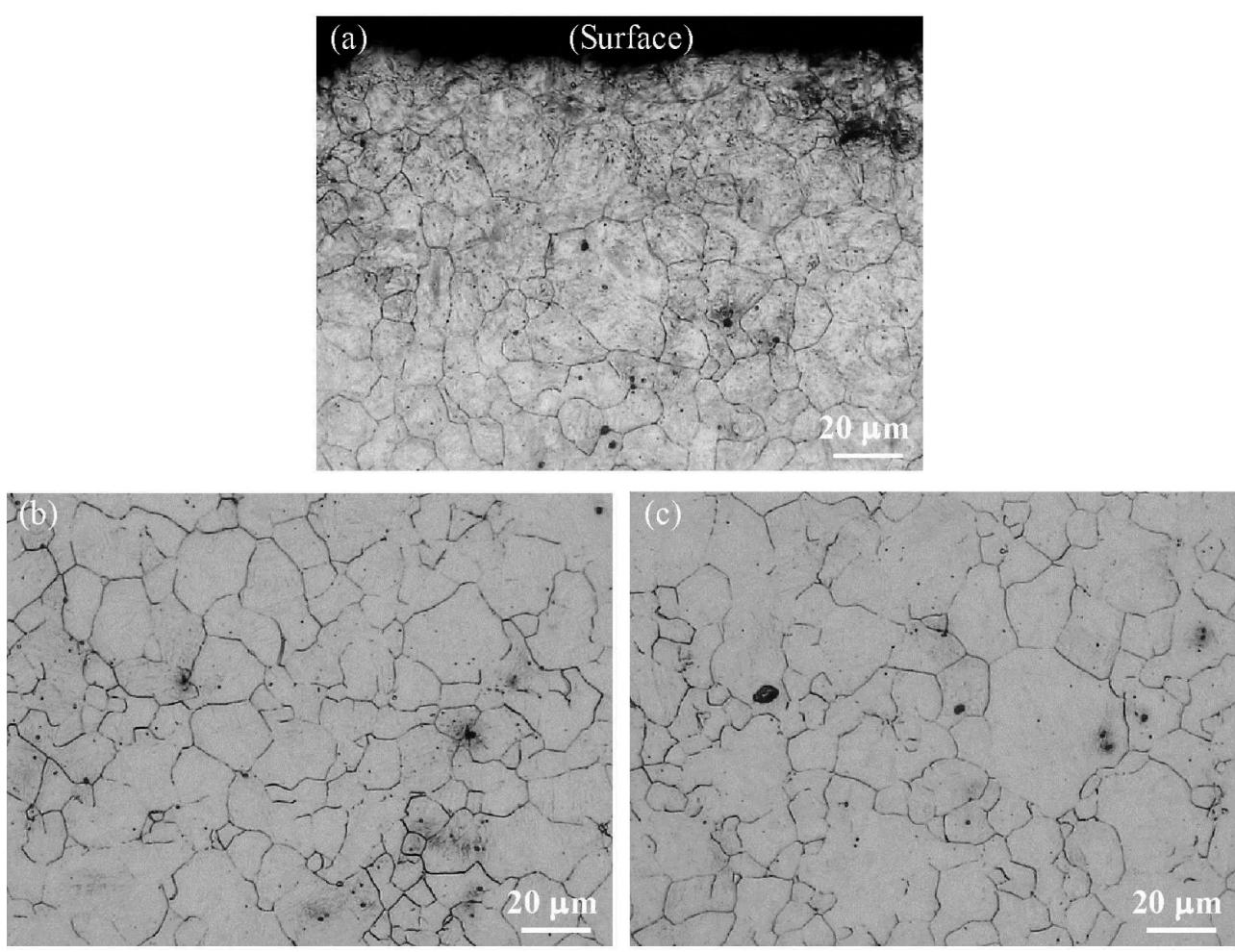

Fig. 3. Cross-sectional optical micrographs obtained for carburized series (C series) etched with picric acid at (a) surface, (b) $800 \mu \mathrm{m}$ in depth and (c) $2500 \mu \mathrm{m}$ in depth. 
株式会社製MY-30AP。ノズル径 $4 \mathrm{~mm}$ ）を用いて，投射圧力 $0.5 \mathrm{MPa}$, ノズル距離 $50 \mathrm{~mm}$, 処理時間 $30 \mathrm{~s}$, 噴出量 $0.2 \mathrm{~g} / \mathrm{s}$ の条件で実施した。本研究ではカバレージは測定していな いが，粒子を投入する際に振動式フィーダを用いるととも に，小型旋盤を用いて試験片を $600 \mathrm{rpm}$ で回転させること により最小径部の全周にわたって均等に処理が施される よう留意した。その際，一度投射した微粒子は循環使用せ ずに廃棄した。FPPを施した全ての試験片に対して表面の 圧縮残留応力值を測定し, 極端に值の低い試験片は除外し た。

FPPの投射粒子には, Table 3 に示す化学成分を有する鉄 系球状粒子を用いた。本粒子の直径は $106 \mu \mathrm{m} \sim 125 \mu \mathrm{m}$, 平 均硬さは $856 \pm 15 \mathrm{HV}$ (試験力 $0.98 \mathrm{~N}, n=30$ ) である。本 研究では，寸法・形状が同一でありながら，硬さのみ異な る 2 種類の投射粒子を作製するため，受入れ粒子に対して 焼なまし $\left(850{ }^{\circ} \mathrm{C}, 30 \mathrm{~min}\right.$ 保持後に炉冷) を施した。焼なま し粒子の平均硬さは $319 \pm 7 \mathrm{HV}$ (試験力 $0.98 \mathrm{~N}, n=30$ ) で あり，受入れ粒子の硬さと比較して低い。以後，焼なまし 粒子をSoft粒子，受入れ粒子をHard粒子と呼称し，それら を用いて FPPを施した浸炭材をそれぞれC+Soft-FPP材お よびC+Hard-FPP材と呼称する。

\section{$2 \cdot 3$ 試験方法}

試験片の硬さ測定は，マイクロビッカース硬さ試験機を 用いて, 試験力 $0.98 \mathrm{~N}$, 保持時間 $10 \mathrm{~s}$ の条件で試験片最小 径部の横断面の所定の深さにおいて, 各 1 点行った。硬さ 測定用試料は，横断面を切断した試験片をエポキシ樹脂に 埋め，エメリー紙（\#320～\#4000）およびコロイダルシリカ 懸濁液により鏡面状に仕上げた。

残留応力および半価幅の測定には, X線残留応力測定装 置 (パルステック工業株式会社製， $\mu-X 360 n$ ) を用いた。測 定時の照射角度は $35^{\circ}$, 電圧 $30 \mathrm{kV}$, 電流 $1 \mathrm{~mA}$, 照射時間 $120 \mathrm{~s}$ ，測定回折面 (211) の条件のもと，X線の照射管には Crを用いて $\cos \alpha$ 法により試験片軸方向の残留応力值を算 出した。深さ方向の残留応力の変化については, 試験片表 面の直径 $5 \mathrm{~mm}$ の領域を逐次電解研磨し，その都度測定す る方法を採用して検討を加えた。また，疲労過程における 残留応力の解放挙動について検討を加えるため, 応力繰返 し数 $10^{7}$ 回で未破断であった試験片に対して疲労試験後に も表面の残留応力を測定した。さらに, 電圧 $30 \mathrm{kV}$, 電流 $1 \mathrm{~mA}$, 照射角度 $18^{\circ}$, 照射時間 $30 \mathrm{~s}$ ，フェライト (211) 回折 面，オーステナイト (220) 回折面の条件で残留オーステナ イト量の測定を行った。測定装置の詳細については，他の 文献 ${ }^{22)}$ を参照されたい。

Table 3. Chemical composition of shot particles (mass\%).

\begin{tabular}{cccccc}
\hline $\mathrm{C}$ & $\mathrm{Si}$ & $\mathrm{Mn}$ & $\mathrm{P}$ & $\mathrm{S}$ & $\mathrm{Fe}$ \\
\hline 0.72 & 0.27 & 0.3 & 0.017 & 0.009 & Bal. \\
\hline
\end{tabular}

試験片の結晶方位は, 後方散乱電子回折 (Electron backscatterd diffraction: EBSD) により分析した。EBSD分析 は, 加速電圧 $20 \mathrm{kV}$, ステップサイズ $0.3 \mu \mathrm{m}$, 分析領域 100 $\times 100 \mu \mathrm{m}^{2}$, 倍率 500 倍の条件で行った。

疲労試験は, 小野式回転曲げ疲労試験機を用いて試験速 度 $30 \mathrm{~Hz}$, 応力比 -1 , 室温・大気中の条件で行った。得ら れたデータをもとに, 日本材料学会標準『金属材料疲労信 頼性評価標準 $-S-N$ 曲線回帰法一』 ${ }^{23)}$ に従って $S-N$ 線図を 描画し，疲労限度を算出した。一部の試験片については， 超高サイクル域での疲労特性を評価するために疲労試験を 応力繰返し数 $10^{7}$ 回で打ち切らず, 試験を継続させた。

疲労試験後, 走査型電子顕微鏡 (Scanning electron microscope: SEM) および3 次元形状測定機による破面観察 を行い, 破壊起点部を特定した。

\section{3. 実験結果および考察}

\section{$3 \cdot 1$ 硬さ測定結果}

Fig.4に, 各シリーズの横断面における硬さ分布測定結果 を示す。同図より，まず浸炭材 (C材) の硬さ分布に注目す ると, 表面から約 $300 \mu \mathrm{m}$ までの深さにおいてほぼ一定の硬 さ值 (約 $700 \mathrm{HV})$ を示していることがわかる。深さ $300 \mu \mathrm{m}$ 以降において硬さ值は低下傾向を示し，およそ800 $\mu \mathrm{m}$ 以 降の深さでは一定值 (約 $480 \mathrm{HV}$ ) を示した。JIS G 0557 に 準拠して算出した $\mathrm{C}$ 材の有効硬化層深さは580 $\mu \mathrm{m}$, 全硬化 層深さは740 $\mu \mathrm{m}$ であった。また, C材は浸炭層より深い位 置に沶いても As-received材の硬さ $(228 \mathrm{HV})$ と比較して高 い值を示した。これは, 浸炭処理時に生じるマルテンサイ 卜変態に起因するものと考えられる。

次に, FPPによる浸炭材の硬さ変化に注目すると, FPP 材 (C+Soft-FPP材抢よびC+Hard-FPP材) の表面硬さはC材 と比較して高いことがわかる。これは, 微粒子衝突によっ て浸炭組織が改質されたためと考えられる。なお，FPPに よる浸炭材の硬さ上昇幅は投射粒子硬さによって異なり,

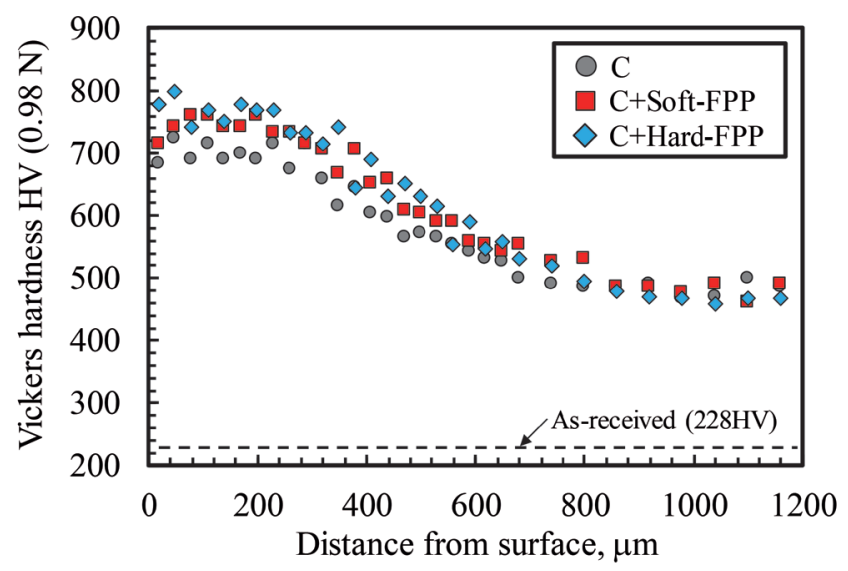

Fig. 4. Distributions of Vickers hardness at cross section. (Online version in color.) 
C+Hard-FPP材の表面において $100 \mathrm{HV}$ 程度の顕著な硬さ上 昇が認められた。

浸炭材の表面硬さがFPP投射粒子硬さに依存して変化 する要因を検討するため, 残留オーステナイト量を測定 した。Fig.5に, FPPを施す前後において, 試験片表面の残 留オーステナイト量を測定した結果を示す。測定は, 試験 片を $90^{\circ}$ ごとに回転させ，同一試験片の最小径部の同一箇 所4点において実施した。同図より, FPPを施す前の試験 片 (C材。図中破線) に約 $20 \%$ 存在していた残留オーステ ナイトは, FPPを施すことにより減少していることがわか る。これは, FPPを施すことにより浸炭層において加工誘 起マルテンサイト変態が生じたことを示唆している。ま た, C+Soft-FPP材の残留オーステナイト量は, C+Hard-FPP 材のそれと比較して高いことがわかる。このことは，投射 粒子が硬いほどFPPによる加工誘起マルテンサイト変態が 顕著に生じることを示す結果である。

以上から，投射粒子の硬さによって FPP時に生じる加工 誘起マルテンサイト変態の程度が変化し, その結果, 浸炭 材の表面硬さが変化することが明らかとなった。

\section{$3 \cdot 2$ 残留応力測定結果}

Fig.6に, 各シリーズの残留応力分布測定結果を示す。な お本研究では, 電解研磨による残留応力の再分配は考慮し ていない。同困から, FPP処理面近傍の圧縮残留応力值は C材と比較して高いことがわかる。これは, FPP時に生じ る加工誘起マルテンサイト変態や加工硬化によるものと考 えられる。また, 表面から 20〜50 $\mu \mathrm{m}$ 以降の深さでは, FPP 材とC材はほぼ同様の分布を示した。

次に，投射粒子硬さの影響に注目すると, C+Hard-FPP材 と比較して C+Soft-FPP材に生起した圧縮残留応力值は低 いことがわかる。これは, Fig.5に示した通り, 投射粒子が 軟らかいほどFPP時の加工誘起マルテンサイト変態量が少

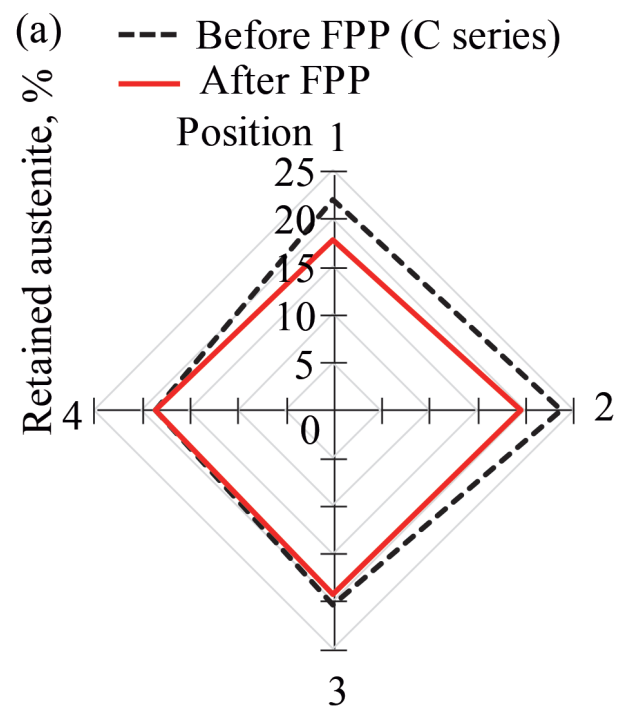

ないためと考えられる。Yonekura $5^{6)}$ は, オーステナイト のマルテンサイト変態時の比容積変化率を用いて, 加工誘 起マルテンサイト変態により生起する圧縮残留応力值につ いて定量的な検討を加えている。したがって, 投射粒子硬 さは, FPP時に生起する圧縮残留応力值にとって重要な因 子であることが明らかとなった。

\section{$3 \cdot 3$ 回転曲げ疲労試験結果}

Fig.7に, 各シリーズの回転曲げ疲労試験結果を示す。同 困（a）にはC 材とAs-received材の結果を示しており，眓中 には疲労限度型片対数折れ線モデルの回帰 $S-N$ 曲線を描画 している。各シリーズの有限寿命域の回帰式は, 以下の通 りである。

$$
\begin{aligned}
& \text { As }- \text { received series }: \sigma_{\mathrm{a}}=-115.34 \log \left(N_{\mathrm{f}}\right)+982.26 \ldots \ldots \ldots \ldots \text { (1) } \\
& \text { C series }: \sigma_{\mathrm{a}}=-307.37 \log \left(N_{\mathrm{f}}\right)+2518.7 \ldots \ldots \ldots \ldots \ldots \ldots \ldots \ldots \ldots \ldots \ldots \ldots \ldots \ldots \ldots \ldots \ldots \ldots
\end{aligned}
$$

ここで, $\sigma_{\mathrm{a}}$ は応力振幅 $(\mathrm{MPa}), N_{\mathrm{f}}$ は破断繰返し数 (cycles)

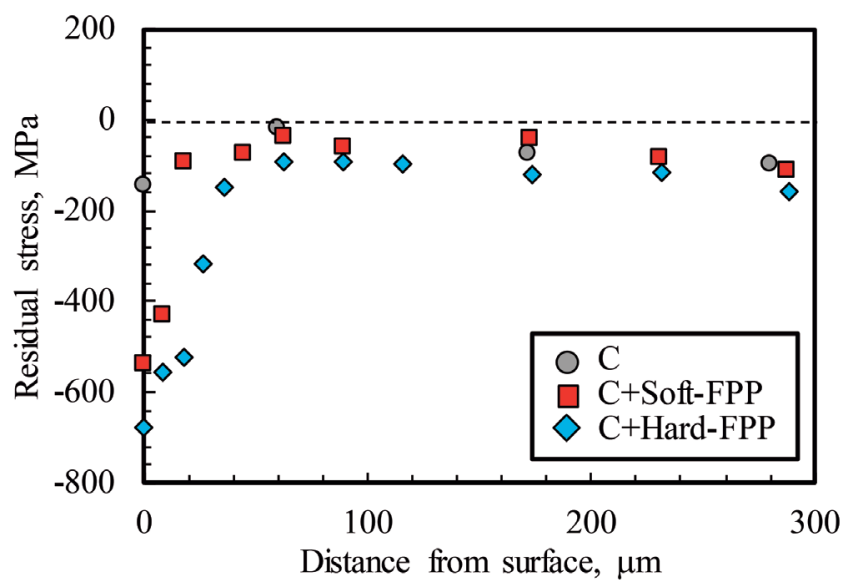

Fig. 6. Distributions of residual stress. (Online version in color.)

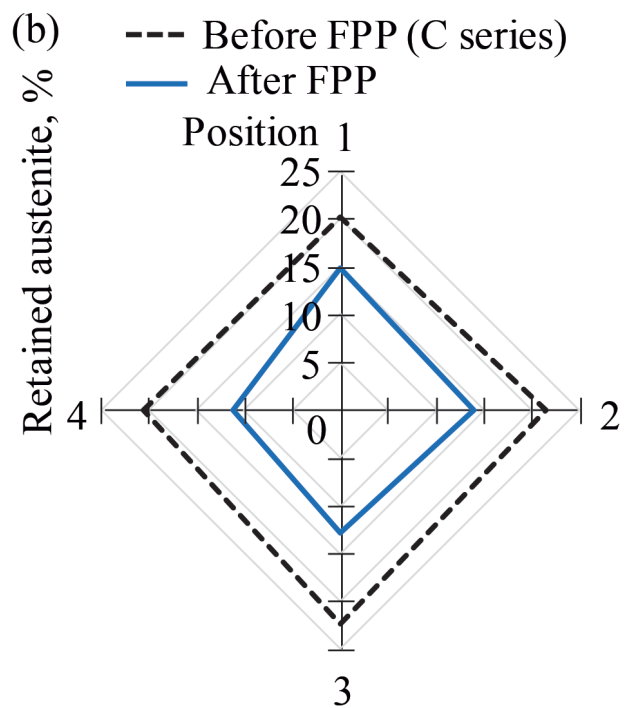

Fig. 5. Changes in retained austenite volume fraction at surfaces of carburized samples (C series) with (a) C+Soft-FPP and (b) $\mathrm{C}+\mathrm{Hard}-$ FPP series. (Online version in color.) 
である。同図 (a)より，C材の疲労限度 (925 MPa) は，Asreceived材のそれ $(383 \mathrm{MPa})$ と比較して高いことがわかる。 これは, Fig.3に示した通り, 浸炭焼入れを施すことにより 硬さが上昇し，疲労き裂の発生抵抗が増大したためと考え
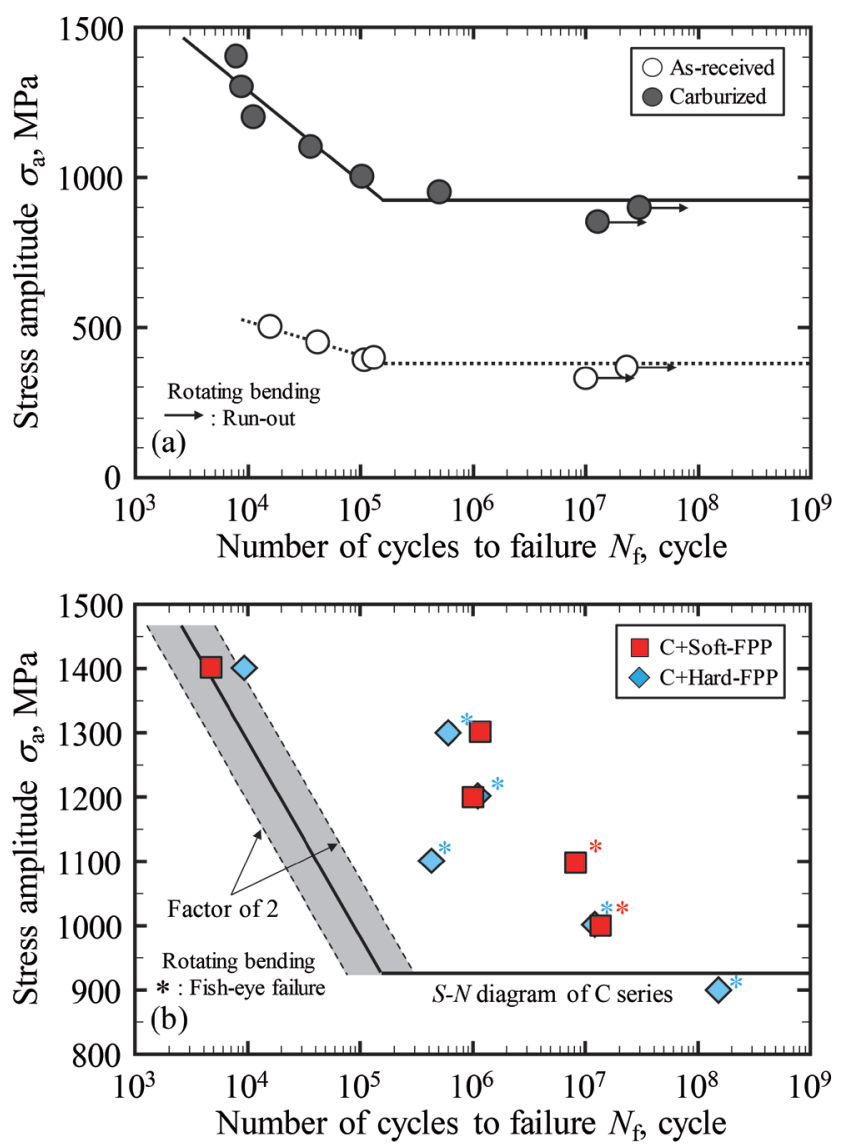

Fig. 7. Results of fatigue tests of (a) as-received and $\mathrm{C}$ series and (b) C+Soft-FPP and C+Hard-FPP series. (Online version in color.)
られる。

Fig.7 (b) に, FPP材 (C+Soft-FPP材およびC+Hard-FPP材) の試験結果を $\mathrm{C}$ 材の回帰曲線とともに示す。なお, FPP 材 は $10^{7}$ 回以上の応力繰返し数においても破断したため, $S-N$ 曲線は描画していない。同図 (b) から, 応力振幅 $1400 \mathrm{MPa}$ で破断したFPP材の疲労寿命は, C材の回帰曲線の Factor of 2 内 (困中の薄墨領域)に収まっており，C材のそれと同 程度であることがわかる。このことは，高応力域において FPPによる疲労特性改善効果が認められないことを示唆し ている。これに対して, 応力振幅 $1300 \mathrm{MPa}$ 以下の試験にお いては, FPP材の疲労寿命はC 材と比較して長いことがわ かる。さらに, 応力繰返し数 $10^{7}$ 回の時点で未破断であった FPP材の負荷応力值 $\left(10^{7}\right.$ 回時間強度 : $\left.1000 \mathrm{MPa}\right)$ は, C材 の疲労限度 $(925 \mathrm{MPa})$ と比較して高いことがわかる。これ らの結果は，投射粒子硬さによらずFPPを施すことにより 浸炭焼入鋼の疲労特性が改善することを示すものである。

次に, 浸炭焼入鋼の疲労特性に及ぼす投射粒子硬さの影 響に注目すると，2つのFPP材の疲労寿命や $10^{7}$ 回時間強度 は同程度であることがわかる。しかし，前節までにおいて， 投射粒子硬さによって FPP材の表面硬さや生起する圧縮 残留応力值が異なることを示した。これらの点を考慮する と, C+Hard-FPP材は表面改質層の特性から期待されるほ どの疲労特性を示していないと考えられる。

この要因を明らかにするため, FPPにより生起した圧縮 残留応力の解放挙動を調べることとした。具体的には, 応 力振幅 $\sigma_{\mathrm{a}}=1000 \mathrm{MPa}$ において, 予め表面の残留応力を測 定した試験片に対して疲労試験を実施し，107回で中途止 めした後に表面残留応力を測定した。Fig.8に, 㽻労試験前 後において FPP材の表面残留応力值を測定した結果を示

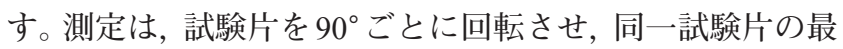

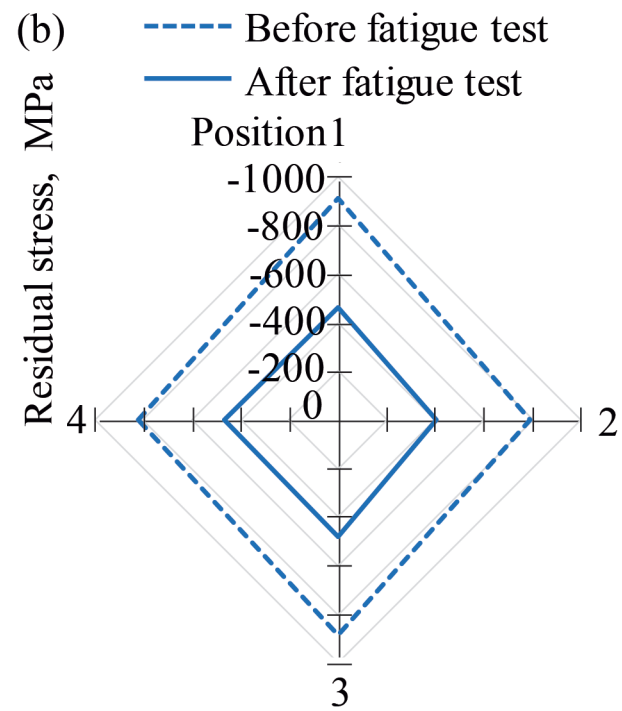

Fig. 8. Changes in compressive residual stress for the (a) C+Soft-FPP and (b) C+Hard-FPP series during fatigue tests. (Fatigue tests condition: $\sigma_{\mathrm{a}}=1000 \mathrm{MPa}, N=10^{7}$ cycles). (Online version in color.) 
小径部の同一箇所 4 点において軸方向に実施した。同図よ り，両材に打いて疲労試験後の圧縮残留応力值 (図中実線) は，疲労試験前のそれ (図中破線) と比較して低いことが わかる。このことは, FPPにより生起した圧縮残留応力が 疲労過程において解放したことを意味している。しかし， 解放後の FPP材の表面圧縮残留応力は, Fig.6に示した C材 の初期圧縮残留応力值 $(164 \pm 19 \mathrm{MPa} . n=8)$ よりも依然 として高い值を示したことから,FPPによる浸炭焼入鋼の 疲労特性改善は圧縮残留応力の生起に起因しているものと 考えられる。なお, FPPによる疲労寿命の増加が認められ なかった高応力域 $\left(\sigma_{\mathrm{a}}=1400 \mathrm{MPa}\right)$ においては, FPPによ り生起した圧縮残留応力の解放が顕著に生じ, C材の值に 漸近する傾向を確認している。
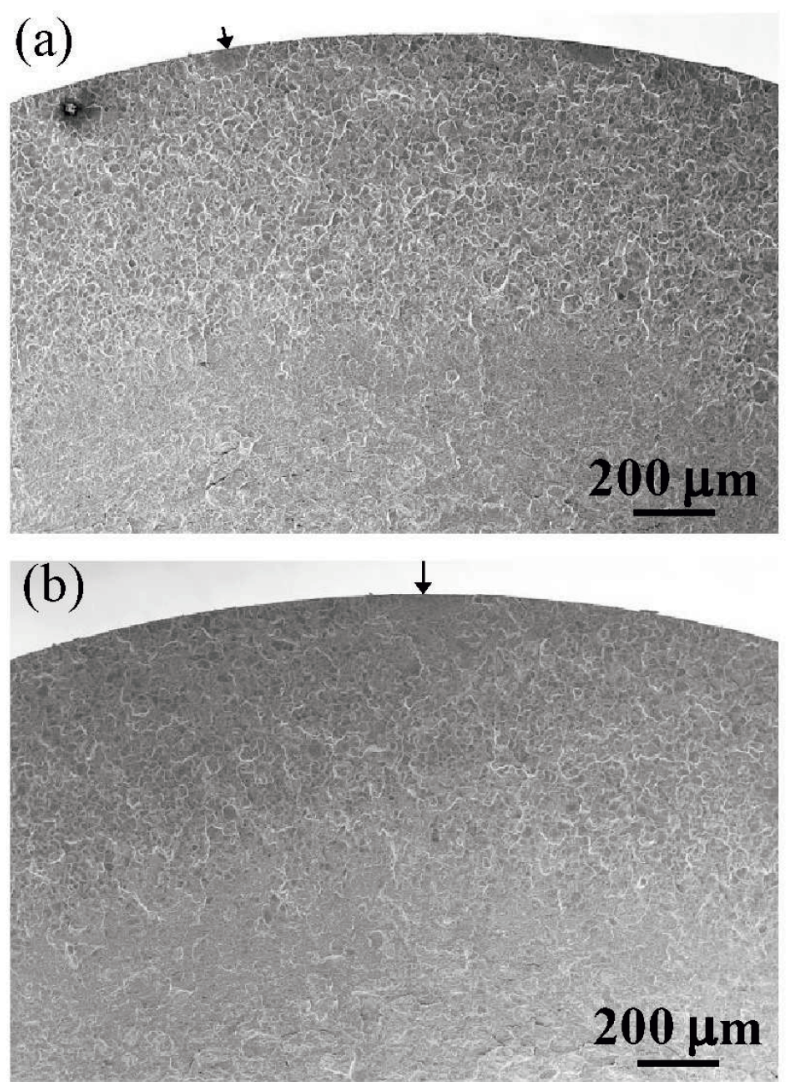

(c) $+$

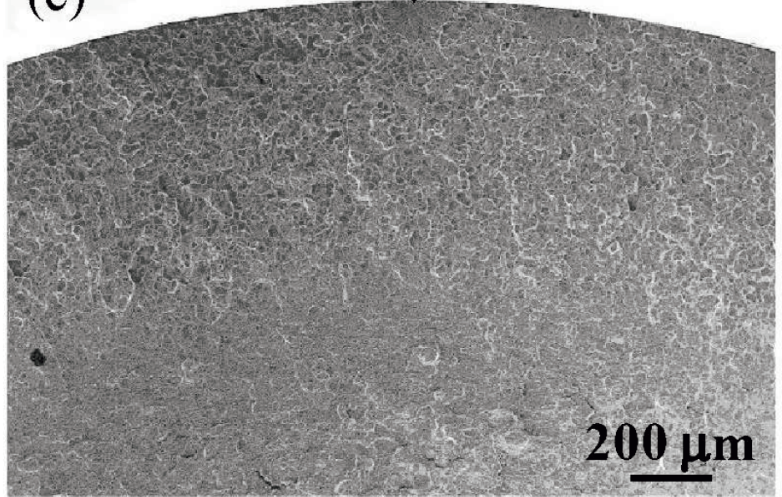

次に, FPP材の測定結果を比較すると, C+Soft-FPP材の 初期圧縮残留応力值は C+Hard-FPP材と比較して低いもの の, 疲労試験後の值は同程度であることがわかる。した がって, 疲労試験後において浸炭焼入鋼の圧縮残留応力值 に及ぼす投射粒子硬さの影響は小さいことが明らかとなっ た。このことが，投射粒子硬さによって初期圧縮残留応力 值が異なるにも関わらず, 両FPP材の疲労寿命や $10^{7}$ 回時 間強度が同程度である要因と考えられる。

\section{$3 \cdot 4$ 破面観察結果}

本節では, Soft-FPPを施した浸炭焼入鋼の疲労破壊入力 ニズムについて検討を加えるため，破面観察を実施した。 まずFig.9に, FPPによる疲労特性の改善が認められなかっ た応力条件 $\left(\sigma_{\mathrm{a}}=1400 \mathrm{MPa}\right)$ にて破断した各試験片の破面
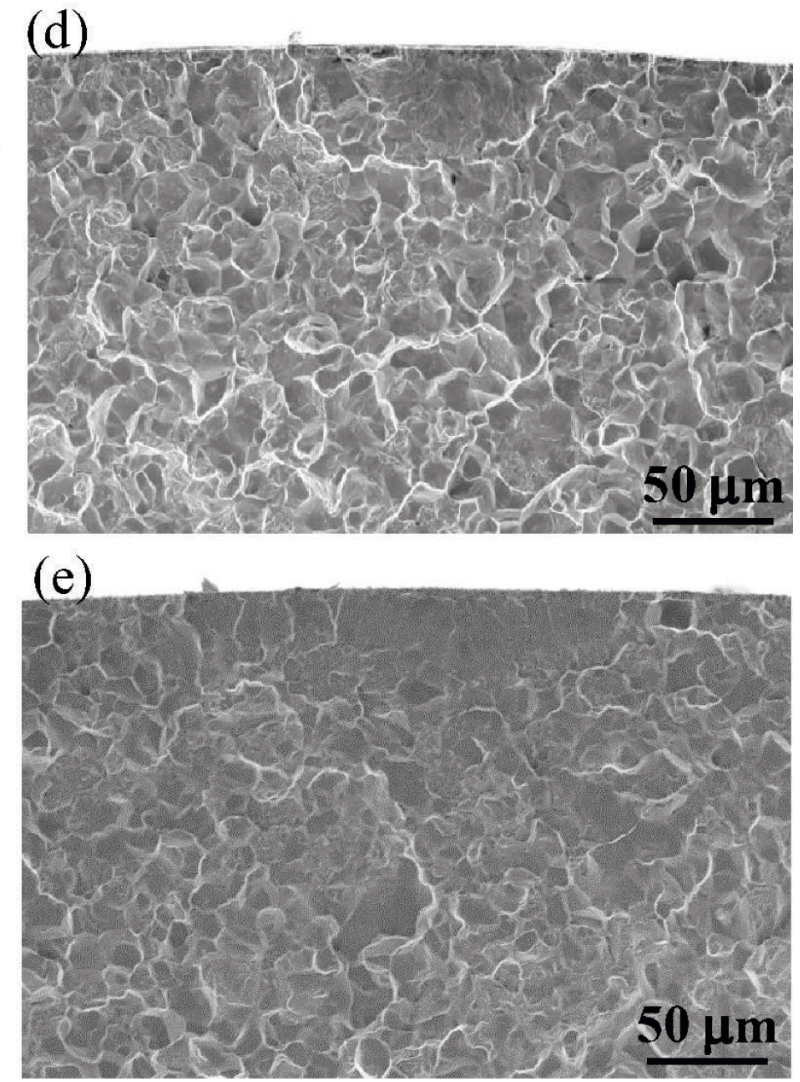

(f)

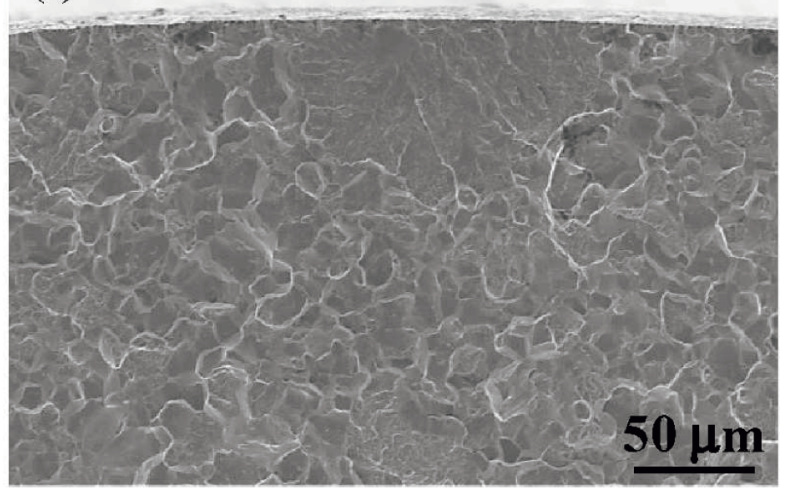

Fig. 9. SEM micrographs of fracture surfaces of the (a),(d) C, (b),(e) C+Soft-FPP and (c),(f) C+Hard-FPP series failed at $1400 \mathrm{MPa}$. (Online version in color.) 
をSEMにより観察した結果を示す。同図 (a) - (c) の低倍 率観察画像から, 応力振幅 $\sigma_{\mathrm{a}}=1400 \mathrm{MPa}$ に扎いて各シリー ズは表面起点型破壊を呈していることがわかる。同図 (d) 一（f）は，同図 (a) - (c) の矢印で示した破壊起点部近傍 を高倍率で観察した結果であるが，全ての試験片シリーズ の表面近傍に拈いて，半楕円状の比較的平坦な領域が形成 されていることがわかる。なお，平坦領域の大きさは試験 片シリーズによって若干異なるものの，破面様相に大差は

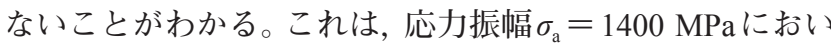
て各シリーズの疲労寿命がほぼ同程度であったためと考え られる。また，平坦領域の周辺では粒界割れの様相を呈し ており，その破面単位の大きさから旧オーステナイト粒界 と推察される。Shin $~^{1)}$ は，ガス浸炭材の粒界近傍におけ る酸素濃度が高いことに起因して, 疲労き裂が結晶粒界を 進展しやすいことを報告している。次に，FPPによる疲労 寿命の増加が認められた応力振幅 $\sigma_{\mathrm{a}}=1200 \mathrm{MPa}$ において 破断した試験片の破面を観察した。Fig.10に，3次元形状測 定機による破面のマクロ観察結果を示す。Fig.10 (a) およ び (b)より，C材およびC+Soft-FPP材は表面起点型の破壊 形態を呈していることがわかる。これに対して, C+HardFPP材の破面にはFish-eyeが明瞭に観察され, 内部起点型 破壊を呈していることがわかる（Fig.10 (c))。

内部破壊を呈したFPP材の破面様相について詳細な検討 を加えるため, SEMによる破面観察を行った。Fig.11に, 一
例としてC+Hard- FPP材の Fish-eye 中央における破壊起点 部を観察した結果を示す。同図 (a) は2 次電子像, (b) は凹 凸像，(c) は反射電子像をそれぞれ示している。同四より， 破壊起点部の近傍には細長い特異組織が認められ (Fig.11 (a))，傾斜を有していることがわかる（Fig.11（b)）。反射電 子像（Fig.11（c)）において特異組織は母材と同色を呈して いたことから，C+Hard-FPP材の破壊要因は非金属介在物 ではないと考えられる。なお, エネルギー分散型蛍光 $\mathrm{X}$ 線 分光装置 (Energy dispersive X-ray fuluorescence spectrometer: EDS）による分析に扎いて，元素の偏析は認められなかつ た。本研究では，内部破壊を呈した全てのFPP材において， 破壊起点部に非金属介在物は認められなかった。

ここで, Fig.7 (b) 内の “*”はFish-eye型の内部破壊の発 生を示しているが, C+Soft-FPP材は $1100 \mathrm{MPa}$ 以下の応力 振幅に扎いて内部起点型破壊を呈した。そのため，投射粒 子硬さによらずFPPを施した浸炭焼入鋼の疲労破壊入カニ ズムは本質的に相違ないが, 疲労破壊モードが表面起点型 から内部起点型に遷移する応力は，投射粒子硬さに依存し て異なることが明らかとなった。Itoga $~^{24)}$ は，表面強度を 系統的に変化させた試験片の疲労特性を検討し, 表面強度 が低いほど表面起点型破壊から内部起点型破壊に遷移す る応力值が低下することを明らかにしている。本研究の場 合, FPP投射粒子が硬いほど表面硬さが増加することを考 慮すると, C+Soft-FPP材の表面強度はC+Hard-FPP材と比
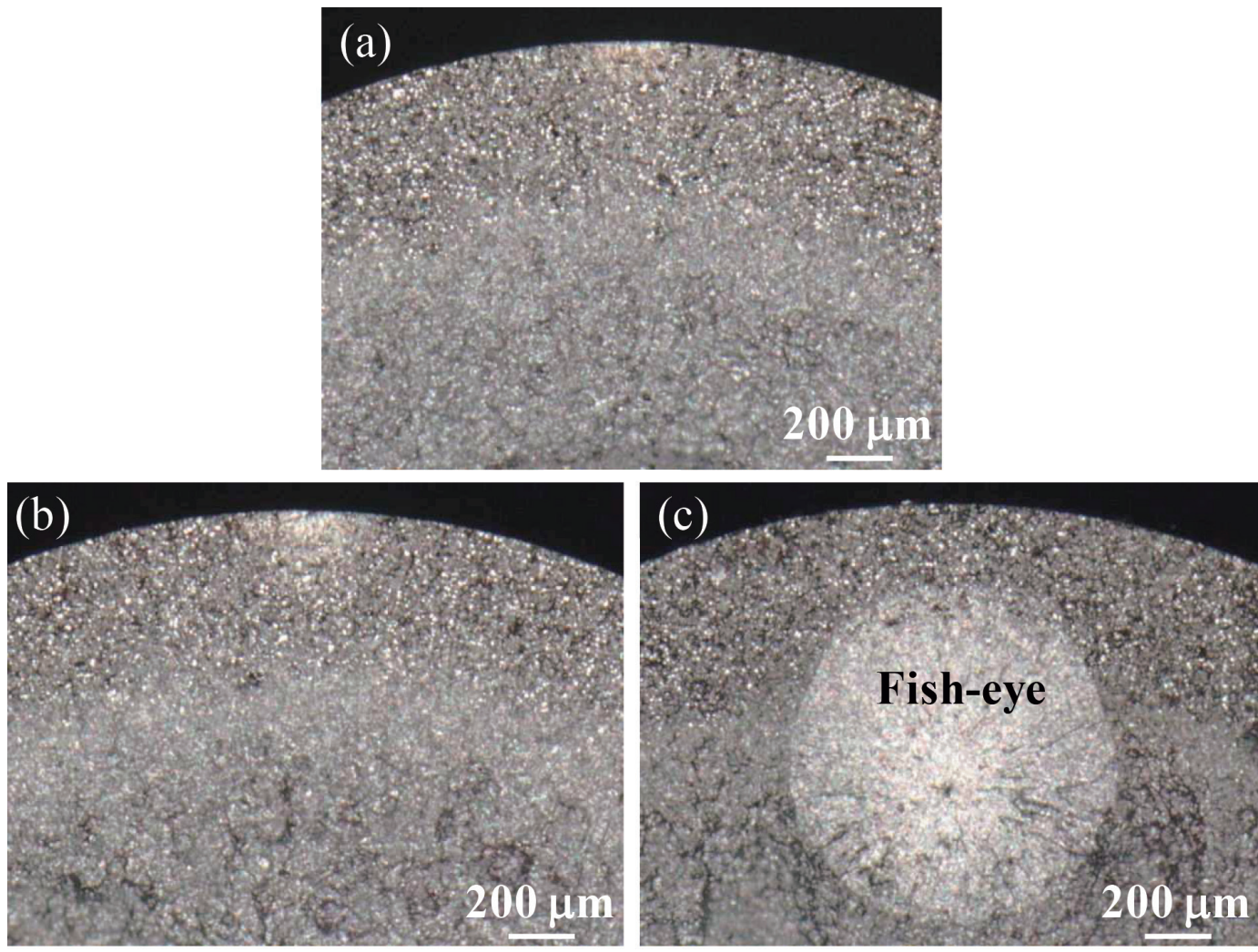

Fig. 10. Optical micrographs of fracture surfaces of the (a) C, (b) C+Soft-FPP and (c) C+Hard-FPP series failed at 1200 MPa. (Online version in color.) 
較して低いと考えられる。なお, FPP材の表面強度を議論 する場合, 表面粗さ值も重要因子となりうるが, 本研究で は前述の硬さの比 (投射粒子硬さを被処理材硬さで除した (值) ${ }^{14,15)}$ が 1.3 未満の条件でFPPを施しているため, C+SoftFPP材とC+Hard-FPP材の表面粗さ值は同程度であった。 そのため, C+Soft-FPP材の破壊モード遷移応力值（1100～ $1200 \mathrm{MPa})$ はC+Hard-FPP材のそれ（1300～1400 MPa）と比 較して低下したと考えられる。

以上から, FPPを施した浸炭焼入鋼において, 表面から 内部へ破壊モードが遷移する応力值は投射粒子硬さによっ て変化することが明らかとなった。

\section{3 ・5 FPPを施した浸炭焼入鋼における内部起点型破壊メカ ニズムの検討}

前節において, FPPを施すことにより浸炭焼入鋼の疲労 破壊モードが変化することが明らかとなった。本節では, FPPを施した浸炭焼入鋼の内部破壊発生要因について考察 を加える。

非金属介在物が起点とならない内部起点型破壊について は, ベイナイト ${ }^{25)}$ やフライト ${ }^{26)}$ が破壊起点となること が報告されている。著者ら ${ }^{21,27,28)}$ も表面処理を施したばね 鋼や低合金鍛鋼において, 非金属介在物を起点としない内 部破壊が生じることを明らかにしている。この点に注目し て, Fig.11に示した破面上に観察された起点組織を EBSD により結晶方位解析を行う手法 ${ }^{29-32)}$ を適用したが, 表面凹
凸によって明瞭な菊池パターンを得ることができなかっ た。そこで, 鏡面状に仕上げた浸炭材の横断面組織の結晶 方位解析を行った。なお, 浸炭層とその内部では組織形態 が異なるため ${ }^{33)}$, 後述する内部破壊起点深さを考慮して浸 炭層直下の組織を分析した。Fig.12に，浸炭層直下に対し てEBSD分析を行うことにより得られた各マップを示す。 同困 (a) はIPF map, 同図 (b) は方位差 $15^{\circ}$ 以上の境界を示 したGrain boundary map, 同図 (c) はPhase mapである。同 困から，浸炭材の組織はFig.1に示した受入れ材とは異な り，針状のマルテンサイトが形成されているがわかる。ま た同罒に抏いて, Fig.11に示した内部破壊起点組織の大き さ・形状に類似した組織が存在していることがわかる。本 研究においても比較的低強度の内在組織がFPP材の内部破 壊起点になったと推測されるが, 内部破壊起点組織の全容 解明は今後の課題である。

Fig.13に, 破面観察結果から測定したFPP材の破壊起点 深さを示す。同図から, FPP材の破壊起点部は, 負荷した応 力振幅值によらず浸炭層直下 (厚さ約 $740 \mu \mathrm{m}$ ) 付近である ことがわかる。このことから, FPPを施した浸炭焼入鋼の 場合, 浸炭層直下の組織を起点とした疲労破壊が試験片の 破断を導くものと考えられる。

この点を検証するため, 破壊起点部に負荷される応力振 幅 $\sigma_{\mathrm{a}, \text { local }}(\mathrm{MPa})$ を式 (3) により求めた。
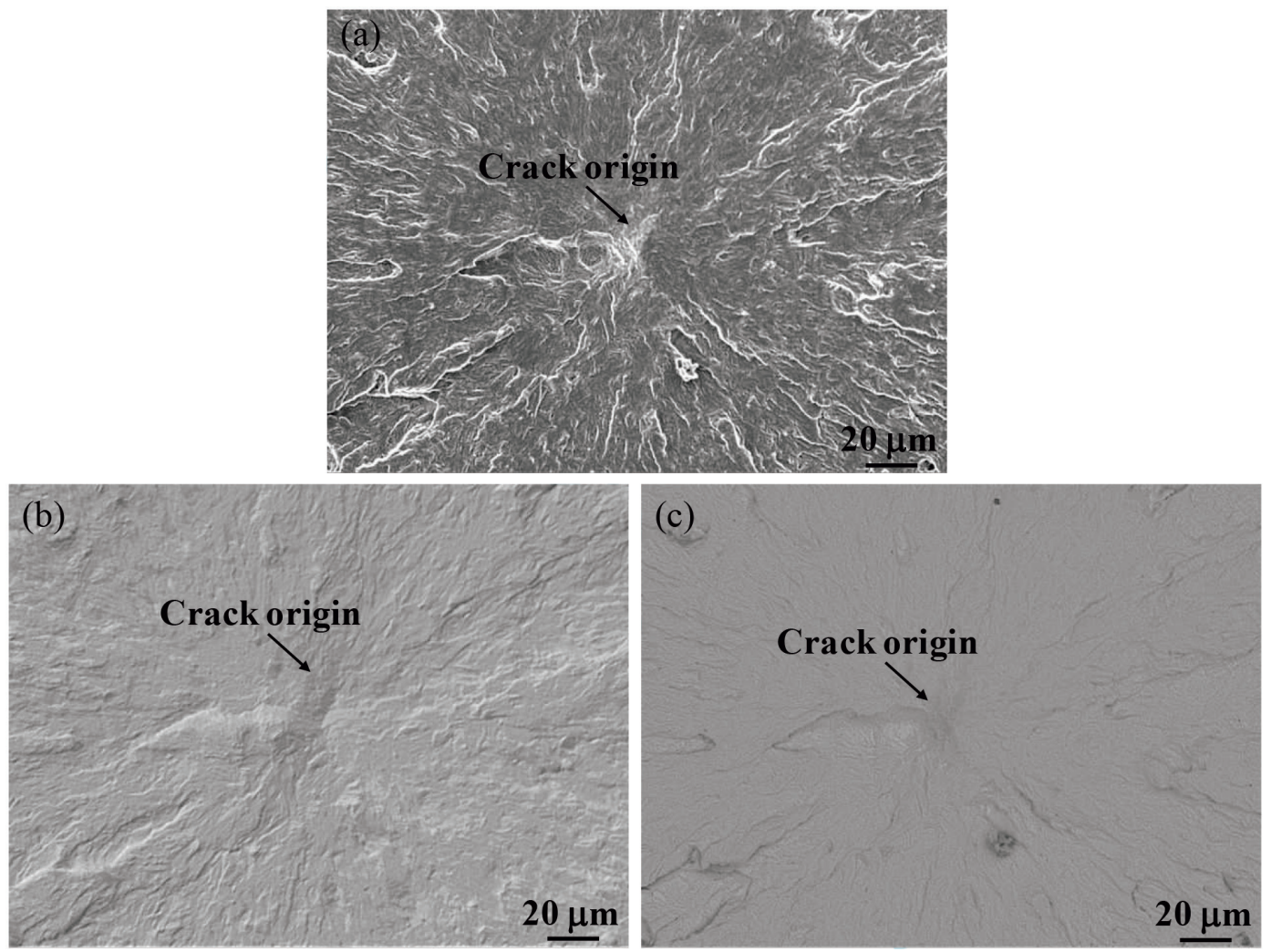

Fig. 11. SEM micrographs of fracture surface of the C+Hard-FPP series failed at $1200 \mathrm{MPa}$. ((a) SE, (b) TOPO and (c) BSE images). (Online version in color.) 


$$
\sigma_{\mathrm{a}, \text { local }}=(1-2 d / D) \sigma_{\mathrm{a}}
$$

ここで, $d$ は破壊起点深さ $(\mathrm{mm}), D$ は試験片の最小断面 直径 $(\mathrm{mm}), \sigma_{\mathrm{a}}$ は公称曲げ応力振幅 $(\mathrm{MPa})$ であり, 試験片 $\mathrm{R}$ 部の応力集中を考慮せず曲げ応力が半径方向において線
形的に変化するとみなして $\sigma_{\mathrm{a}, \text { local }}$ を算出した。

Fig.14に, 破壊起点部に負荷される応力振幅 $\sigma_{\mathrm{a}, \text { local }}$ で再 整理した疲労試験結果を示す。同図から，投射粒子硬さ とは無関係に, 有限寿命域の全てのプロットは同一バン

ド内（図中破線付近）に収まっていることがわかる。さら に, その破壞応力は, 全て表面破壊した $\mathrm{C}$ 材の疲労限度
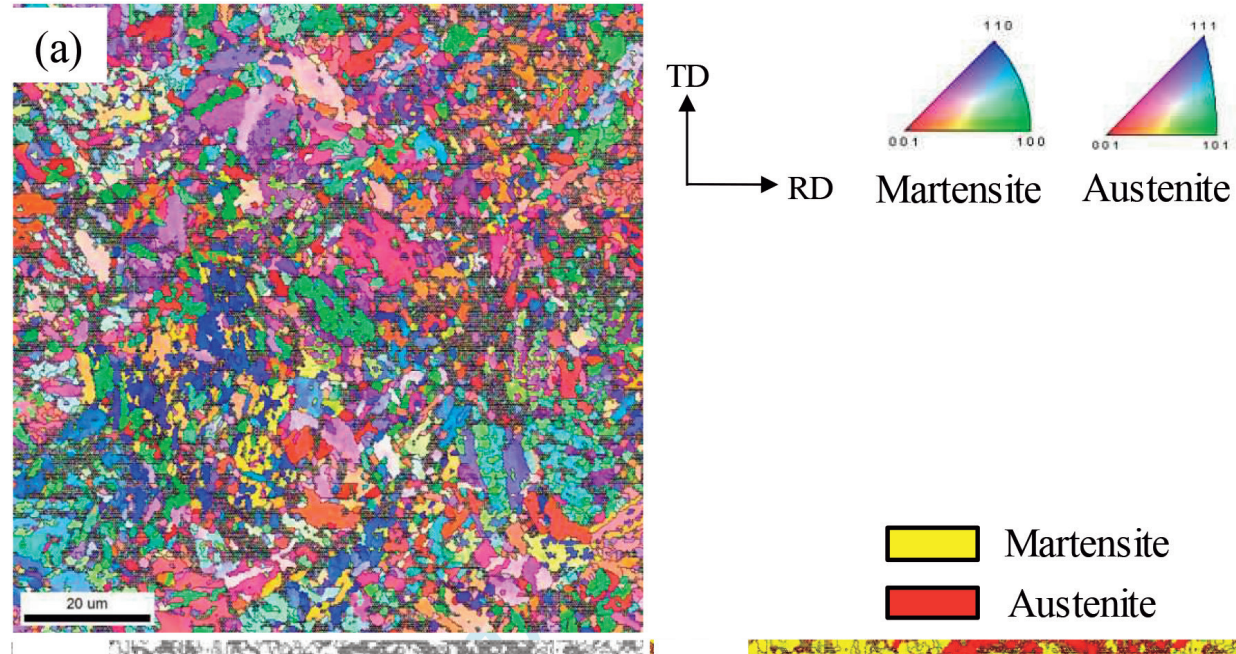

(b)

\section{(c)}
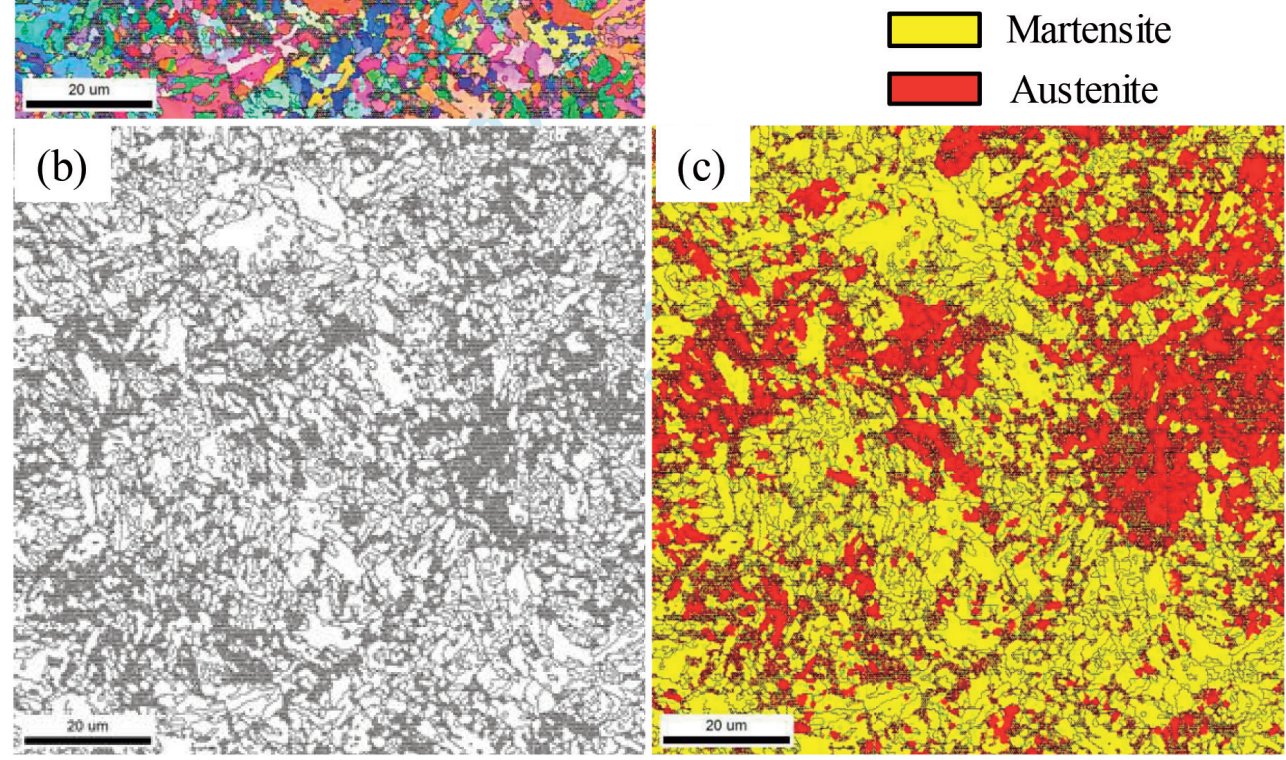

Fig. 12. (a) IPF map, (b) grain boundary map and (c) phase map obtained by EBSD analysis for carburized sample (C series) beneath the carburized layer. (Online version in color.)

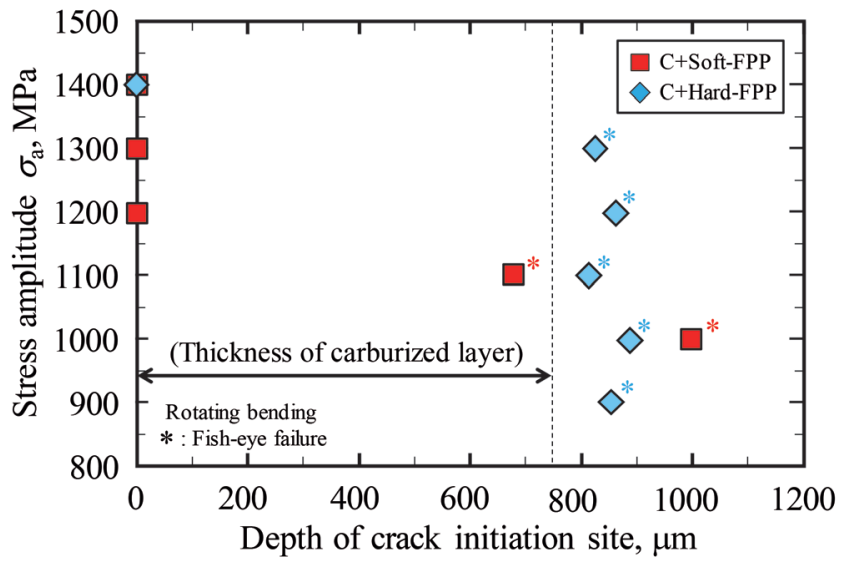

Fig. 13. Depth of fracture origin of the C+Soft-FPP and $\mathrm{C}+$ Hard-FPP series. (Online version in color.)

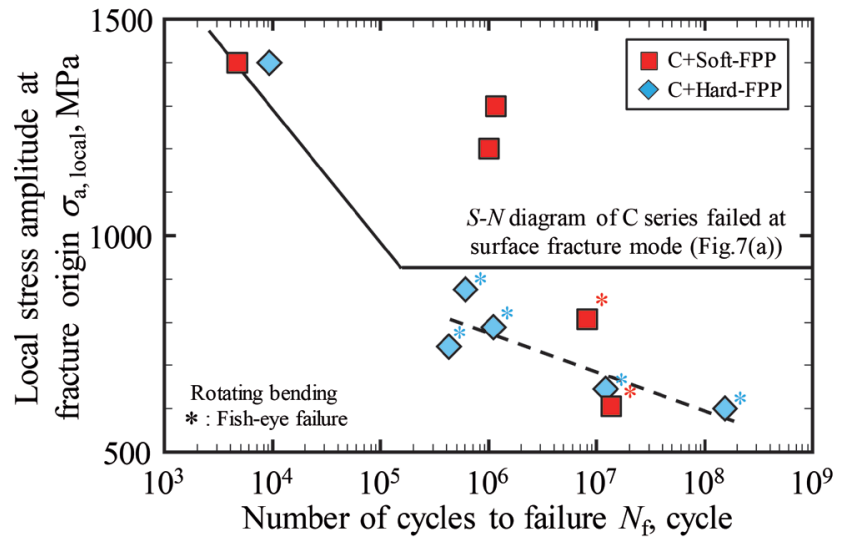

Fig. 14. Results of fatigue tests in terms of local stress amplitude at fracture origin. (Online version in color.) 
（925 MPa）と比較して低いことがわかる。このことは, FPP を施した浸炭焼入鋼の内部疲労破壊が, 浸炭層直下の低強 度組織に負荷される応力值により決定されることを示すも のである。したがって, Fig.7 (b) で述べたFPPによる疲労 寿命の増加は, 公称応力振幅 $\sigma_{\mathrm{a}}$ で試験結果を整理した場合 に発現し, 表面起点型から内部起点型への破壊モード遷移 および応力勾配に起因する見かけの現象と考えられる。し かし, C+Soft-FPP材の疲労寿命は, 表面起点型破壞におい てもC材と比較して大幅な増加が認められたことから, 軟 質FPPによる表面強化の効果は発現していると考えられ る。なお, 内部破壞寿命は起点深さや起点組織の大きさ等 によってばらつくため, 高応力振幅付近では表面破壊寿命 曲線と内部破壞寿命曲線が混在する領域であったと推測さ れる。

Fig.15に，硬さの異なる投射粒子を用いたFPPによる浸 炭焼入鋼の疲労特性変化を表す概念図を示す。なお，同図 の実線は実験結果をもとに描画した表面起点型破壊の寿命 曲線を, ハッチング領域は内部起点型破壞の寿命曲線を示 している。投射粒子硬さによらず, FPPにより生起した圧 縮残留応力や硬さ上昇の効果に起因して浸炭焼入鋼の疲労 寿命や $10^{7}$ 回時間強度は増加する。一方, 負荷応力の低下に 伴い, 表面起点型破壊から, 低強度の内部組織を起点とす る破壞モードに遷移する。その際, 疲労破壞モードが表面 起点型から内部起点型に遷移する負荷応力值は, FPP投射 粒子硬さに依存して変化し, 硬質の投射粒子を用いて FPP を施した場合に高い值を示す。しかし，FPPにより生起し た圧縮残留応力は疲労試験中に解放されるため, 浸炭焼入 鋼の瘦労寿命および $10^{7}$ 回時間強度に及ぼす投射粒子硬さ の影響は小さい。

本研究では浸炭焼入鋼に対してFPPを施したが, 内部破 壊が生じない低・中強度鋼を対象とした場合, 軟質FPPに よる疲労特性改善効果はさらに高まると考えている。具体

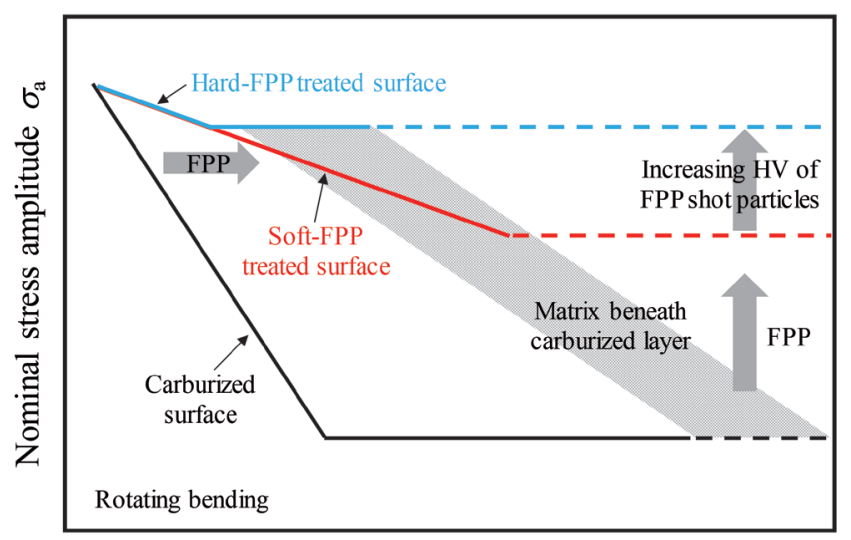

$\log$ (Number of cycles to failure $N_{\mathrm{f}}$ )

Fig. 15. Schematic $S-N$ diagrams showing the effect of shot particles hardness used in FPP on fatigue properties of carburized steels. (Online version in color.)
的には, 疲労過程における圧縮残留応力の解放を鑑みる と, 硬質の投射粒子を用いるFPPにより高い圧縮残留応力 の生起に注力するのではなく, 軟質 FPPによる被処理面の 塑性変形の抑制に起因して表面粗さの低減や寸法精度の維 持などの利点が得られることが期待され ${ }^{34)}$, 今後の検討課 題としたい。

\section{4. 結言}

本研究では, ガス浸炭焼入れを施したクロムモリブデ ン鋼の回転曲げ疲労特性に及ぼす軟質微粒子ピーニング (Soft-FPP) の影響について検討を加えた。具体的には, 硬 さの異なる投射粒子を用いた FPPによる表面性状変化や疲 労過程に打ける圧縮残留応力解放挙動と関連付けて, 軟質 FPP 施した浸炭焼入鋼の疲労破壞メカニズムについて検 討を加えた。以下に得られた知見を示す。

(1) FPPに用いる投射粒子の硬さに依存して, 浸炭組織の 加工誘起マルテンサイト変態の程度は変化する。

(2) 上記 (1) の現象に起因して, 投射粒子硬さの増加に伴 い, 表面硬さの上昇幅打よび生起する初期圧縮残留応 力值は増加する。しかし, 疲労過程において圧縮残留 応力は解放されるため, 疲労試験後の表面圧縮残留応 力值に及ぼす投射粒子硬さの影響は小さい。

(3) 軟質FPPを施すことにより, 浸炭焼入鋼の疲労寿命打 よび $10^{7}$ 回時間強度は増加する。

（4）軟質 FPP を施すことにより浸炭焼入鋼の疲労破壞モー ドは表面起点型から内部起点型に遷移する。その際, 破壞モードの遷移応力値は硬質の投射粒子を用いた場 合と比較して低いが, FPPを施した浸炭焼入鋼の疲労 寿命や $10^{7}$ 回時間強度は投射粒子硬さによらず同程度 である。

\section{謝辞}

本研究は, (公財) スズキ財団科学技術研究助成金の補助 のもと行った。また，本研究を実施するにあたり，日本材 料学会疲労部門委員会『疲労に関する表面改質分科会』, 静 岡大学坂井田喜久先生, 早川邦夫先生, 藤井朋之先生, 鈴 木宽史氏, 伊東航希氏, 南澤健太氏, ヤマ八発動機株式会 社太田敏也氏, 井上陽一氏にご協力いただいた。記して謝 意を表す。

\section{文献}

1 ) D.M.Shin, C.Y.Lee and K.S.Lee: ISIJ Int., 42(2002), 1042. https:// doi.org/10.2355/isijinternational.42.1042

2 ) T.Koyama, M.Kubota and S.Yoshida: ISIJ Int., 56(2016), 1638. https://doi.org/10.2355/isijinternational.ISIJINT-2016-149

3 ) H.Morikawa, M.Nakae and K.Nishiyama: J. Jpn. Soc. Abras. Technol., 63(2019), 315 (in Japanese). https://doi.org/10.11420/ jsat.63.315 
4 ) M.Yoshizaki: Trans. Jpn. Soc. Mech. Eng. C, 73(2007), 1931 (in Japanese). https://doi.org/10.1299/kikaic.73.1931

5 ) N.Egami, C.Kagaya, N.Inoue, H.Takeshita and H.Mizutani: Trans. Jpn. Soc. Mech. Eng. A, 66(2000), 1936 (in Japanese). https://doi. org/10.1299/kikaia.66.1936

6 ) D.Yonekura, J.Komotori, M.Shimizu and H.Shimizu: Trans. Jpn. Soc. Mech. Eng. A, 68(2002), 509 (in Japanese). https://doi. org/10.1299/kikaia.68.509

7 ) T.Sawada: J. Jpn. Inst. Met. Mater, 78(2014), 388 (in Japanese). https://doi.org/10.2320/jinstmet.J2014004

8 ) T.Sawada: J. Jpn. Inst. Met. Mater., 78(2014), 211 (in Japanese). https://doi.org/10.2320/jinstmet.J2013077

9 ) D.Yonekura, J.Noda, J.Komotori, M.Shimizu and H.Shimizu: Trans. Jpn. Soc. Mech. Eng. A, 67(2001), 1155 (in Japanese). https://doi. org/10.1299/kikaia.67.1155

10) S.Kikuchi and J.Komotori: J. Soc. Mater. Sci., Jpn., 66(2017), 535 (in Japanese). https://doi.org/10.2472/jsms.66.535

11) T.Morita, H.Nakaguchi, S.Noda and C.Kagaya: Mater. Trans., 53(2012), 1938. https://doi.org/10.2320/matertrans.M2012226

12) K.Nambu and S.Kikuchi: J. Jpn. Soc. Abras. Technol., 59(2015), 525 (in Japanese). https://doi.org/10.11420/jsat.59.525

13) S.Kikuchi and J.Komotori: J. Jpn. Soc. Abras. Technol., 54(2010), 720 (in Japanese). https://doi.org/10.11420/jsat.54.720

14) S.Kikuchi, Y.Hirota and J.Komotori: J. Soc. Mater. Sci., Jpn., 60(2011), 547 (in Japanese). https://doi.org/10.2472/jsms.60.547

15) M.Omiya, S.Kikuchi, Y.Hirota and J.Komotori: J. Solid Mech. Mater. Eng., 4(2010), 1585. https://doi.org/10.1299/jmmp.4.1585

16) T.Morita: Mech. Surf. Tech., 34(2016), 36 (in Japanese).

17) J.Arakawa, T.Hanaki, Y.Hayashi, H.Akebono and A.Sugeta: Fatigue Fract. Eng. Mater. Struct., 43(2020), 211. https://doi.org/10.1111/ ffe.13097

18) J.Arakawa, M.Kakuta, Y.Hayashi, R.Tanegashima, H.Akebono, M.Kato and A.Sugeta: Surf. Eng., 30(2014), 662. https://doi.org/10.1 179/1743294414Y.0000000308

19) T.Ochi, S.Kozawa and M.Kubota: Tetsu-to-Hagané, 97(2011), 486 (in Japanese). https://doi.org/10.2355/tetsutohagane.97.486

20) S.Kikuchi, Y.Nakamura, K.Nambu and M.Ando: Mater. Sci. Eng. A, 652(2016), 279. https://doi.org/10.1016/j.msea.2015.11.076

21) S.Kikuchi, R.Yakura, N.Fujitsuna, H.Takaoka, T.Ikegami,
M.Matsuda, T.Miura, A.Ueno and T.Sakai: J. Soc. Mater. Sci., Jpn., 66(2017), 893 (in Japanese). https://doi.org/10.2472/jsms.66.893

22) H.Nozue and M.Yamaguchi: J. Surf. Finish. Soc. Jpn., 67(2016), 27 (in Japanese). https://doi.org/10.4139/sfj.67.27

23) Standard Evaluation Method Of Fatigue Reliability For Metallic Materials -Standard Regression Method Of S-N Curves-, The Society of Materials Science, Kyoto, (2007).

24) H.Itoga, K.Tokaji, M.Nakajima and H.N.Ko: J. Soc. Mater. Sci., Jpn., 54(2005), 1249 (in Japanese). https://doi.org/10.2472/jsms.54.1249

25) T.Toriyama, Y.Murakami, T.Yamashita, K.Tsubota and K.Furumura: Tetsu-to-Hagané, 81(1995), 1019 (in Japanese). https://doi. org/10.2355/tetsutohagane1955.81.10_1019

26) Y.Kuroshima, M.Shimizu and K.Kawasaki: Trans. Jpn. Soc. Mech. Eng. A, 59(1993), 1001 (in Japanese). https://doi.org/10.1299/ kikaia.59.1001

27) T.Miura, T.Sakakibara, T.Kuno, A.Ueno, S.Kikuchi and T.Sakai: Key Eng. Mater, 664(2016), 209. https://doi.org/10.4028/www.scientific. net/KEM.664.209

28) T.Miura, T.Sakakibara, S.Mimura, T.Kuno, S.Kikuchi, A.Ueno and T.Sakai: J. Soc. Mater. Sci., Jpn., 64(2015), 613 (in Japanese). https:// doi.org/10.2472/jsms.64.613

29) S.Kikuchi and Y.Nakai: J. Jpn. Soc. Powder Powder Metall., 66(2019), 97 (in Japanese). https://doi.org/10.2497/jjspm.66.97

30) Y.Nukui, H.Kubozono, S.Kikuchi, Y.Nakai, A.Ueno, M.O.Kawabata and K.Ameyama: Mater. Sci. Eng. A, 716(2018), 228. https://doi. org/10.1016/j.msea.2018.01.054

31) S.Kikuchi, Y.Hayami, T.Ishiguri, B.Guennec, A.Ueno, M.Ota and K.Ameyama: Mater. Sci. Eng. A, 687(2017), 269. https://doi. org/10.1016/j.msea.2017.01.076

32) S.Takesue, S.Kikuchi, H.Akebono, T.Morita and J.Komotori: Results Mater., 5(2010), 100071. https://doi.org/10.1016/ j.rinma.2020.100071

33) Y.Sakaida, T.Inayama and S.Yashiro: J. Soc. Mater. Sci., Jpn., 63(2014), 557 (in Japanese). https://www.jstage.jst.go.jp/article/ jsms/63/7/63_557/_article/-char/ja/

34) K.Nambu and M.Okumiya: Proc. 7th Int. Conf. on Fracture Fatigue and Wear (FFW 2018), ed. by M.Abdel Wahab, Springer, Switzerland, (2019), 390. https://doi.org/10.1007/978-981-13-0411835 